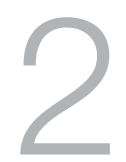

\title{
Road pricing and road provision in Australia: Where are we and how did we get here?
}

\author{
Michael de Percy
}

\section{In the beginning}

British settlement of Australia began in 1788 and, from the outset, governments of all persuasions imposed strong 'statist' traditions of public ownership and control of important infrastructure. Economic development and physical access across the continent were dependent on statist investment, construction and maintenance of crucial infrastructure—often called the 'colonial liberalist' legacy by subsequent historians. State intervention was accepted as a basic requirement of social progress and economic development and, over time, Australia became locked in a 'path dependency' paradigm reliant on state provision and regulation of vital infrastructure. Accordingly, the provision of modes of transport across the continent and the policy dictates associated with the crucial issues of provision and usage were framed within a particularly statist mindset. Roads, rail, shipping and river transport, as well as bridges, jetties and wharves (and later air transport), were all historically financed and governed by dirigisme and by institutional arrangements, rather than market-based measures such as private investment, private provision and 
consumer charging. ${ }^{1}$ Arguably, command-driven public provision and the arbitrary governmental regulation of transport infrastructure came at a cost to the overall productivity and efficiency of each type of infrastructure and the interconnectivity between them. And we are still living with the legacy of this pattern of state activism in the funding and provision of transport infrastructure.

The development of the railways across Australia is a good example. Colonies, and later states, invested heavily in extensive rail networks, opening up land and forests, connecting farms and towns and servicing urban areas. Rail was more important than roads. States funded these networks with capital borrowed from British banks, thereby generating enormous state debts at the subnational level. While the Commonwealth gradually had to assist in repaying these debts, the states guarded their individual rail systems with monopolistic regulations imposed on usage (and, to some extent, by formulating non-standard specifications such as different rail gauges - an early form of regulatory protection). Rail preferencing, especially for the movement of freight, was a feature of Australian development for almost a century. As Hancock (1930: 55) argued during this period, Australia ' $[\mathrm{h}]$ as come to look upon the State as a vast public utility, whose duty is to provide the greatest happiness for the greatest number'.

He continued (Hancock 1930: 110, 112-13), using the vast state railways as an example:

Let us consider the railways, for upon them rests the economic structure of each one of the States. In 1927-28 nearly one-half of the existing public debt of the States had been incurred on their behalf. In that year the deficits to which all the Australian railways confessed amounted to about $£ 5,500,000$. Yet in the three years prior to the war the railways had (at least in appearance) paid their way; they had even contributed to the various treasuries an aid of about $£ 800,000$. The difficulties of railways in post-war years, and particularly the difficulty of competing with road transport, are notorious all the world over ... So, then the railways become an instrument for subsidizing 'development', for promoting decentralization for protecting local industry, for cherishing Naboth, for inaugurating the new social order. But this is confusion. The railways are not really an effective instrument for these assorted purposes. All these

1 There were a few isolated examples of private provision of infrastructure—such as bridges and toll roads - but these were usually gradually incorporated into state-provided systems (see Sturgess 1996). 
miscellaneous demands upon their good nature make it more difficult for them to fulfil their own essential purpose, which is to provide adequate transport for goods and passengers at the lowest possible cost.

Hence, rail transport dominated the movement of freight and passengers until a 1954 decision by the Privy Council in London ended the protection of state government-owned railways (The Age 1954: 3). This decision to break the rail monopoly was historically significant in that, once these institutional barriers were removed, the majority share of the volume of freight moved by land transport shifted from rail to road. Coastal shipping-which was to some extent in competition with rail—had steadily declined and effectively disappeared from the transport policy narrative by this time (Fitchett 1976: 7). Indeed, only very recently have the institutional arrangements for coastal shipping been identified as barriers to increasing its share of bulk freight transport (Standing Committee on Infrastructure, Transport, Regional Development and Local Government and King 2008).

The legacy of the regulatory arrangements regarding rail freight, shipping and road haulage did not encourage active competition to increase efficiencies and contain costs between the different transport modes, or lead to better integration and interoperability. Indeed, the reverse occurred. When the highly regulated institutional arrangements that governed the state-owned and operated rail networks (which also allowed them to recover their costs) were eventually dismantled, the state rail systems soon became poorly performing commercial ventures, unable to pay their way, and experienced a long-term historical decline accompanied by the wholesale closure of branch-line rail networks. By contrast, road freight transport had been captured by private hauliers and transport firms who, along with passenger transporters and private motorists, all viewed roads and the road systems as free 'public goods', provided from general taxation by governments to connect regions and communities. Such thinking meant that while governments were pressured to invest in new roads and development road projects, they did not raise sufficient funds from road users to fund road building or to reflect the costs of road maintenance. In other words, while governments were forced to expand their road networks, it was difficult for them to efficiently charge road users for the full costs of provision and capture negative externalities such as the cost of maintenance. This discrepancy created subsequent problems for intermodal competition in that the cost of road transport was heavily subsidised, whereas rail was meant to be operated on a cost-recovery 
basis, even though many rail lines, in fact, lost money. Moreover, governments found that they were expected to replicate the existing rail corridors and connections, which, arguably, led to the misallocation of investment dollars.

A second legacy of the earlier dominance of rail monopolies resulted in a general decline in road provision and maintenance (BTE 1977: 387). With the changed regulatory environment after the 1950s, and as freight and passenger movement became more reliant on the road network, state governments with relatively small tax bases struggled to fund improvements to their road systems. This gradually led to a greater role for the Commonwealth to fund national highways through the annual tied grants programs. Increased specific commitments by the Commonwealth for the funding of major road infrastructure improvements have been a feature of federal-state relations since the 1960s. However, despite the Commonwealth's involvement and the increasing importance of the road network, and the extent of the National Competition Policy reforms of the 1980s, Australia's road infrastructure remains the 'least reformed of all infrastructure sectors, with institutional arrangements around funding and provision remaining much the same as they were 20 years ago' (Harper et al. 2015: 28-30).

Regulatory reform in the road transport sector has focused mainly on issues of road safety, vehicle inspection and heavy vehicle regulation. As the quantity and capacity of heavy road vehicles increased, governmental attention to road usage increased exponentially-directed mainly towards the levels of investment in and maintenance of roads, and often related to safety measures. By the 2010s, while rail still dominated bulk freight transportation (carrying cargo such as coal, iron ore and grain; see Figure 2.1), road haulage dominated the non-bulk freight task (Figure 2.2). This pattern has been manifested since deregulation of road transport took effect in the early 1970s (BTE 1977). In recent decades, the propensity of rail to carry bulk freight and for non-bulk freight to go by road has increased sharply. By contrast, coastal shipping tonnages have remained largely stable, although the sector's share of the freight task has declined in relation to road and rail. The 2008 Coastal Shipping Inquiry conducted by the Australian Parliament acknowledged that this declining share in the freight task means more freight on road and rail services, which are already under pressure. 


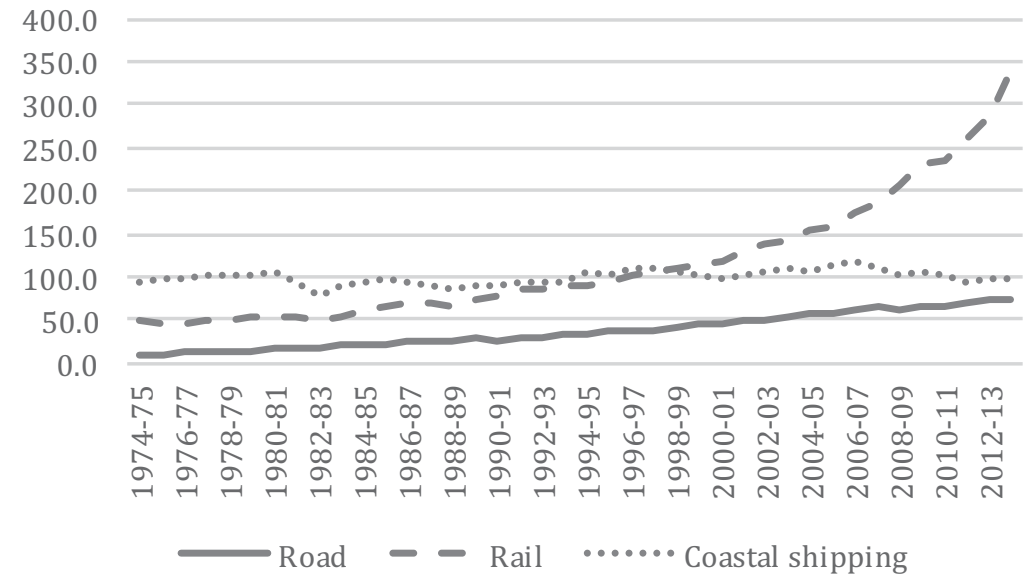

Figure 2.1 Bulk freight task by mode (billion tonne kilometres)

Source: BITRE (2016: Table T 2.1a).

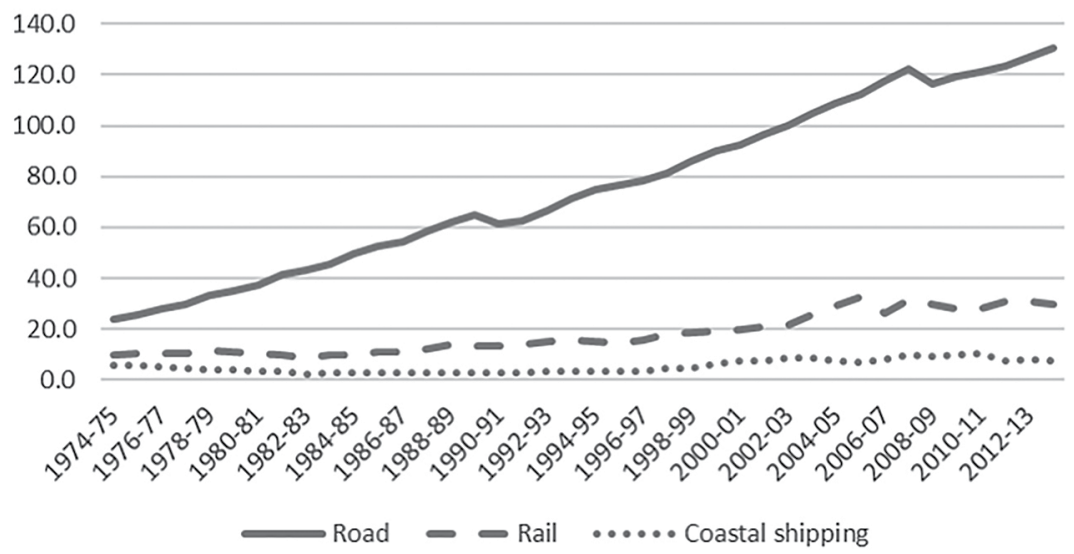

Figure 2.2 Non-bulk freight task by mode (billion tonne kilometres)

Source: BITRE (2016: Table T 2.1b).

The complex relationship between road and rail transport in Australia not only has a long history, but also has many dimensions and paradoxes. As railways were deployed, there was a tendency for roads to be left to decline or remain unsealed. Until the 1954 Privy Council decision, rail passenger travel was heavily cross-subsidised by requirements that all freight of a certain size and moving over a certain distance had to travel by rail. As a result, state railways tended to operate at a surplus. Only after the Privy Council decision enabled competition from road transport did the state railways begin to run at a loss. So, over time, the waxing and waning of the 
road and rail transport industries were largely due not to the commercial disciplines of the market, but to the consequences of policy decisions and the regulatory framework. The pattern of 'trading off' between road and rail modes may have occurred out of economic necessity and, for the most part, the supply of passenger and freight transport options in the past was at least adequate to meet the demands of population growth and the level of economic activity. In the present, however, the current supply of both road and rail transport infrastructure in Australia is nowhere near meeting demand. Furthermore, projections into the next 30 years suggest the consequences of inadequate investment in transport infrastructure, coupled with the inefficient transport behaviour of users, will lead to significant costs and a potential lowering of the standard of living. Nevertheless, ways of dealing with these issues have been proposed for some time.

\section{Changing paradigms: Pricing, planning and behaviour}

Celebrated economists and urban planners such as Arthur Pigou (pricing) and Le Corbusier (planning) identified issues affecting the pricing and planning of road networks as early as the 1920s. Pigou (1920) proposed a tax to equal negative externalities, and his ideas were taken up by William Vickrey $(1948: 227 ; 1963: 457)$, who saw them as a means to introduce congestion charging to influence the behaviour of road users and investors. In planning, Le Corbusier (1987) examined the long-term impact of historical legacies on the roads of Paris from the Middle Ages, which were based on the easiest routes for pack animals to negotiate. He considered this pattern obsolete and contemplated the complete replacement of existing thoroughfares to make them more suited for automobiles. For Le Corbusier, the complete redesign and rebuilding of road systems was required, rather than tinkering with existing networks, which would not solve the basic problems.

Australian governments have, over time, acknowledged these two major issues of pricing and planning. However, the challenges of recalibrating the entire system of transportation have proved to be politically difficult. The task would have involved two aspects. First, governments would have had to undo the legacy of an (inadequate) cost-recovery funding system that has been collected predominantly through general taxes and 
flat levies, with no obvious correlation between road use and taxes paid. Second, and following that, governments would have to overcome the legacies of past transport infrastructure planning and design, where rail routes, for example, were based on the capacity of steam locomotives, ventured to remote parts of the states and connected long-exhausted remote mining ventures or small rural towns. In more recent times, these routes did not efficiently connect the major country towns, nor were they optimal to provide services to travellers.

In Australia, road and rail transport infrastructure has remained largely under government ownership and control, and therefore negative externalities have been captured through taxation more generally (and often via policies focused on specific issues such as transport safety, noise, environmental pollution and urban renewal). Further, state governments have adopted a variety of planning responses, ranging from the organic (Sydney, Brisbane) to the planned (Melbourne, Adelaide, Perth). There is some irony, however, in the different outcomes of the two approaches. For example, Sydney addressed the traffic congestion problem created by rail level crossings early in its history, partly because of geography, but also because of the sprawling nature of the city and its traffic routes. Melbourne, on the other hand, with its light rail network and orderly road system, did not focus on the removal of level crossings until an allocation in the 2015-16 budget, with the removal of some 50 level crossings required to improve safety and congestion, to be conducted over eight years. Further, Melbourne has only recently addressed the legacies of the light rail network's outdated congestioncausing rail tracks crisscrossing the centre of the city. The combination of pricing and planning legacies has led to numerous responses from government, but usually pricing emerges as a way to fund critical new infrastructure that may or may not have been in the 'pipeline' of major infrastructure projects.

The challenges created by historical legacies are numerous and relate to issues ranging from planning approval (such as 'corridor preservation') to behaviours around the use of the infrastructure (such as an expectation that roads are public goods and therefore their use should be free to all). Road user charges, or tolls, have been used sparingly by Australian governments to recover the costs of investment-in particular, for infrastructure projects such as the Sydney Harbour Bridge and Brisbane's Gateway Bridge and for a web of tunnels carrying freeway traffic under city centres, rivers and harbours. While improved engineering methods 
allowed the Hume Highway to be rerouted to bypass smaller towns and to make road travel between Sydney and Melbourne faster and safer, many of the existing rail lines in New South Wales (NSW), Victoria and South Australia still follow routes designed around the limitations of steam-driven engines to connect farming communities. While there are now more private toll roads and private railways in Australia, road and rail infrastructure generally remains under government control, with the Commonwealth assuming an increasing political role for the allocation of road funding. In recent years, the Commonwealth has sought to claim some 'dividend' from its partial asset ownership in such projects, but states and territories have been reluctant to engage with them on this matter; the Commonwealth could impose its preferences by insisting payments of dividends from recipient states become a condition of specific-purpose payment funding (and most likely the states would be reluctantly forced to accede).

Throughout the various states and territories, existing road user charges are based on a 'two-part tariff model, where road users pay a flat 'network access charge' (state-based motor vehicle registration fees tied to vehicle size and/or location) and a quasi user charge based on fuel consumption (the Commonwealth's fuel excise on petrol, diesel and liquid petroleum gas, or LPG). However, there is no obvious link between these charges and investment in and maintenance of roads. Nor is there a close link between these fees and levies and actual patterns of usage or usage in times of high congestion. For instance, a driver travelling $10,000 \mathrm{~km}$ in Sydney's central business district (CBD) would pay exactly the same fuel excise as a driver covering the same distances on virtually unused country roads. Increasingly, fuel efficiency has also reduced the amount of revenue raised through the fuel excise, with those owning older cars tending to pay more for their use of the roads than those driving more efficient vehicles. While heavy vehicles pay higher fees for road use and access, there is no direct link between the damage done by these vehicles and the resulting cost of maintenance.

When the goods and services tax (GST) was introduced in 2000, the indexation of fuel excise was temporarily discontinued. Despite the fuel excise being increased biannually in line with the consumer price index (CPI) since 2014, revenue from fuel excise continues to decline and local governments-responsible for the majority of roads-still struggle to find adequate funds to maintain existing roads. Meanwhile, the Commonwealth-which has no direct constitutional responsibility 
for roads, and in fact owns or controls very few roads on the continenthas taken on a greater role in funding roads through successive federal governments using road funding as a major policy platform for electioneering purposes. The result has been to increase the availability and capacity of roads, without an increase in funding to maintain either existing or new roads.

Australia has reached the point where, in the future, the consequences of 'doing nothing' will inevitably lead to increasing costs. This will be due to massive traffic congestion in the major cities, fuelled by population growth, rising affluence and unchecked demand. Moreover, there will be a decreased capacity for freight and passenger movement on the road network due to a lack of upgrading and maintenance. When combined with the lack of investment in alternative transport modes-particularly high-speed rail—there are few incentives for motorists or truck operators to change their behaviour and reduce demand on the existing road infrastructure. Evidence from overseas jurisdictions, such as California, clearly indicates that states cannot build their way out of traffic congestion; they merely add to it exponentially. Indeed, increasing the capacity of roads simply increases the demand for them, and reinforces existing road use behaviours. It creates perverse logics and outcomes.

Following this argument, it is apparent that two things need to occur on the policy front. First, there needs to be an increase in investment in alternative transport modes, particularly rail, which can move freight and greater numbers of people efficiently and speedily. Second, there needs to be a way to modify the current behaviour of road users to encourage efficient use of existing roads. Planning and pricing, then, are the keys to improving the efficiency of passenger and freight transport in Australia. The problems, of course, are first, how to prioritise and fund infrastructure projects and, second, and much more importantly, how to garner political support for an appropriate road pricing system so that the patterns of usage change to facilitate network efficiencies and maximise user satisfaction.

At the heart of the public policy problem is the entrenched perception of roads as a free public good for which users do not need to pay (despite roads not being wholly a 'public good' in definitional terms; one person's enjoyment of the good can impact on another's enjoyment through congestion). Users see roads and their usage of them more or less as an inalienable 'right', and itemised payments for the use of roads through tolls and charges as an annoying infringement of these same rights. Road tolls 
of even miniscule levels irritate passenger vehicle drivers beyond belief, and where specific toll-based infrastructure is built to alleviate congestion it is not clear that truck drivers or tradespeople who have to pay the toll personally (not their firms) will take the optimal option. Part of the problem is that road users do not experience the charges they are already paying for road access and use as that use actually occurs. Tolls, however, provide a point-of-sale signal, whether a beep on the dashboard or an online credit card payment, which clearly links usage with the price.

This problem is further exacerbated by the lack of a direct link between road user charges and investment in transport infrastructure and maintenance. The current two-part tariff does not provide users (or, indeed, investors) with price signals that can effectively modify behaviour. This occurs because there is no information provided to the consumer at the point of sale that directly correlates with their use of the infrastructure (DIRD 2016: 41). In comparison, consumers of energy, water and telecommunications services will modify their behaviours in the use of these services because there is a clear price signal at the point of sale, and they incur an itemised bill. Hence, the more consumers use the services, the more they pay; therefore, patterns of usage are necessarily constrained by the consumer's budget and their motivation to save money. Road usage is not so rationed or priced to change unnecessary usage or usage in peak congestion periods. We pay the price of congested usage indirectly in time by waiting in queues and enduring endless traffic jams, but we do not count the collective cost of these wasted hours, fuel, mental frustration and opportunities in terms of what other useful things those trapped in the endless tailgates could undertake.

While paying excise taxes for fuel does represent a quasi user charge, as the number of fuel-efficient vehicles increases, these price signals are decreasing accordingly. Yet, road users continue to use roads without paying directly for the proportionate use of them (or the congestion they cause) and, as the revenue from the fuel excise declines, governments increasingly pick up the tab for the supply and maintenance of road infrastructure, despite increasing demand by road users. This means that low-volume users of roads, and those with less fuel-efficient vehicles, are cross-subsidising high-volume users. It also means that the true cost of road freight is not being captured in the price of freighted goods. Consumers still pay the price for these externalities through increased taxes and other opaque input charges, but the price is not visible to the consumer, nor does it factor to change their behaviour. 
With general levies and charges there are no clear signals for the demand for transport infrastructure beyond the collective voice of road users in their dissatisfaction with traffic congestion or poorly maintained roads. The same principle applies to road freight. Rather than improving rail freight services, policy thinking is dominated by road freight to such an extent that addressing shortfalls in the non-bulk freight task has led to calls to increase the capacity of freight trucks-from B-double to B-triple. Such thinking sees consideration of the externalities relating to road safety, increased maintenance costs due to rampant damage of road surfaces and increased congestion on major freight routes relegated to the achievement of the freight carrying task. It is interesting that road freight, using vehicles with ever-increasing capacities, is being considered on the Hume Highway (connecting Sydney and Melbourne) when there is an existing viable railway line between the two major cities. Given that a freight train can move maybe 1,000 times more than a single B-triple truck and, additionally, the rail network suffers less from use than the road network, it is arguable that externalities relating to road network use are not being captured appropriately in the price of road freight.

Not surprisingly, then, rail industry advocates have been major supporters of road pricing reform, with a rail inquiry and numerous reports by the Australasian Railway Association recommending road pricing as a means to improve intermodal competition. It is interesting that the rail industry is now in a similar position to that of the road transport industry before the 1954 Privy Council decision. Then, competition between rail and road was prevented by legislation. Now, competition between rail and road is reduced by the subsidisation of road transport inherent in the two-part tariff system and the funding of road infrastructure through unrelated revenue streams. Rail transport tends to be more expensive as the price of rail travel reflects more of the costs of inputs and usage than the price of road travel. It may be said, then, that the existing system encourages freight behaviours based on inadequate pricing signals. Rather than encourage improvements in rail infrastructure, perceptions of cheaper prices associated with road freight, particularly at the point of sale, encourage increased capacity in the existing system, leading to the problems discussed above.

Similar behaviours can be observed among business investors weighing up potentially profitable infrastructural investments, despite increased interest from superannuation and private equity funds in investing in infrastructure (Anthony 2016; Desloires 2016). The preponderance 
of infrastructure 'announcements' by various Australian governments for electioneering purposes (pork-barrelling), coupled with established attitudes and behaviours towards road usage, has tended to restrict the private sector's role in building infrastructure to public-private partnerships (PPPs) with government. While this is not necessarily a bad thing, it means that transport infrastructure is captured by political processes rather than by clear economic principles. Conversely, it may be said that there is more to life than economic efficiency, but given the economic consequences of the status quo are forecast to reduce Australia's living standards and, indeed, our quality of life, it is important that the way we conduct planning, provision and use of transport infrastructure leads to increases in economic efficiency. There is much literature to support the need for Australia to do so (see, for example, BITRE 2014; DIRD 2014, 2016; Harper et al. 2015; Henry et al. 2010; Juturna Consulting 2012; Laird 2014; OECD 2010, 2012, 2014, 2017), and motorists in any of Australia's major metropolitan centres are surely aware of the extent of the existing problems with traffic congestion. But whether those same motorists (and also governments) are prepared to change their behaviours to enable the required efficiencies to occur is quite another matter. And, for as long as road funding and provision remain a political rather than an economic issue, without strong leadership, transport reform is unlikely to occur.

\section{Revenue, expenditure and changing perceptions}

The reaction of the Australian public to talk of road user charges has typically remained negative. And the tabloid press has milked the outrage for all it is worth. For example, after colluding with the Sunday Telegraph about the issue of road user charging (O'Rourke 2015), the Daily Telegraph tested a mooted charge of 1.5 cents per kilometre (based on a similar voluntary scheme in Oregon) or a $\$ 10$ congestion charge (which would appear to be based on the London zonal congestion charges) and put these propositions to Sydney residents (O’Rourke 2015). Predictably, there was community outrage. One respondent—a locksmith who travelled $70 \mathrm{~km}$ a day for his business_-preferred things to stay as they were. He believed it was 'not fair if we end up having to pay more to do our jobs just because someone wants to get more cars off the road'. To have to pay for the use of the road-which, to him, was a necessity for his business-even if 
a fuel rebate was applied, would see him 'out of pocket'. Further, the Sunday Telegraph's editorial challenged the fairness of paying a user charge on a road system that was effectively a daily car park, especially when there was no other modal choice available for many users and commuters (Saleh 2015). For users to be asked to pay a charge for use of a road that they seem to have no choice other than to use can be seen as little more than revenue raising, rather than a means of changing behaviours and providing market information. For policymakers, such negative views of road pricing will not be easy to overcome-much like voters' aversion to a value-added or GST consumption tax during the late stages of the twentieth century.

The implementation of the GST (see Chapter 7, this volume) provides an interesting counterfactual to the potential doom surrounding road pricing and, indeed, lessons about how road pricing can be introduced. After years of political debate over the introduction of a consumption tax, it was only through the leadership of John Howard and Peter Costello that the GST came to be. Former Liberal opposition leader John Hewson's infamous GST 'birthday cake' demonstrated the political problem of trying to explain something seemingly simple but technically very complex. Nevertheless, once introduced and despite the political trade-offs with Democrats' leader Meg Lees resulting in a rather narrow conception of the proposed broad-based consumption tax, the GST has not resulted in the doom and gloom predicted before its introduction. Yet the GST was a major reform that, accompanied with lower income taxes, has been generally positive in its impact on individuals and businesses. That is not to say the GST does not require further reform, but the biggest sticking point today with road funding (see Chapter 10) is how we reform the broken system where revenues historically viewed as the purview of the states and collected by state treasuries will be collected and redistributed by the Commonwealth.

Nonetheless, behavioural change by road users will be key to reducing congestion and improving the efficiency of Australia's transport infrastructure. Road and rail infrastructure spending has increased as a percentage of gross domestic product (GDP) in the past decade and grew from 0.69 per cent in 1986-87 to 1.23 per cent in 2015-16 (Figure 2.3). Clearly, the problem is not principally a lack of infrastructure spending, but a case of using the existing infrastructure more efficiently. Moreover, 
road-related revenue and expenditure have been steadily increasing on all fronts and at all levels of government. The details of each part of the revenue and expenditure regime are worth briefly noting.

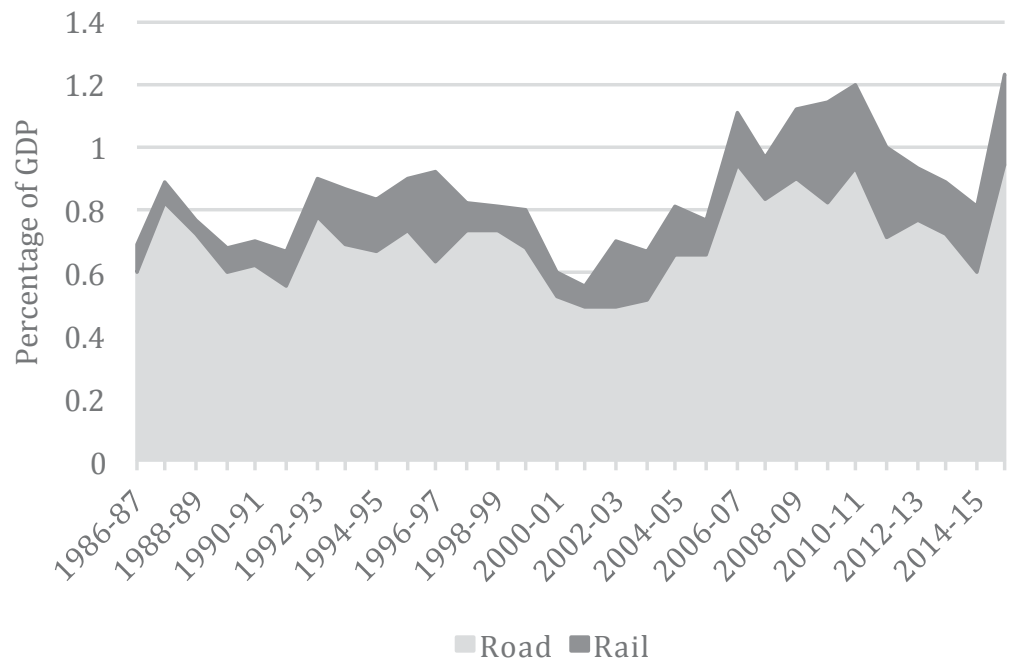

Figure 2.3 Road and rail infrastructure expenditure as a percentage of gross domestic product (GDP)

Sources: ABS (2017a: Table 3; 2017b: Table 11).

Total public sector road-related revenue has steadily risen in the past decade, allowing for the 2008 Global Financial Crisis (GFC) (Figure 2.4). However, the mix of revenue items has changed, with increases in state and territory revenues (Figure 2.5) the most significant growth area in public sector revenue increase (along with the GST on road-related consumption). Of these, the largest growth is evident in the proportion of vehicle registration fees and tolls. While increases in tolls reflect the use of relevant parts of the road network, the network access charge (vehicle registrations) - which tends to reinforce perceptions of roads as public goods-is increasing, providing motorists with a 'double-whammy' effect: increased access fees and charges for sitting gridlocked in traffic. Meanwhile, the fuel excise, which represents a quasi user charge, is declining steadily (Figure 2.6). Road-related expenditure is also increasing across the public sector generally (Figure 2.7) and for the Commonwealth (Figure 2.8), state and territory (Figure 2.9) and local levels of government (Figure 2.10). 


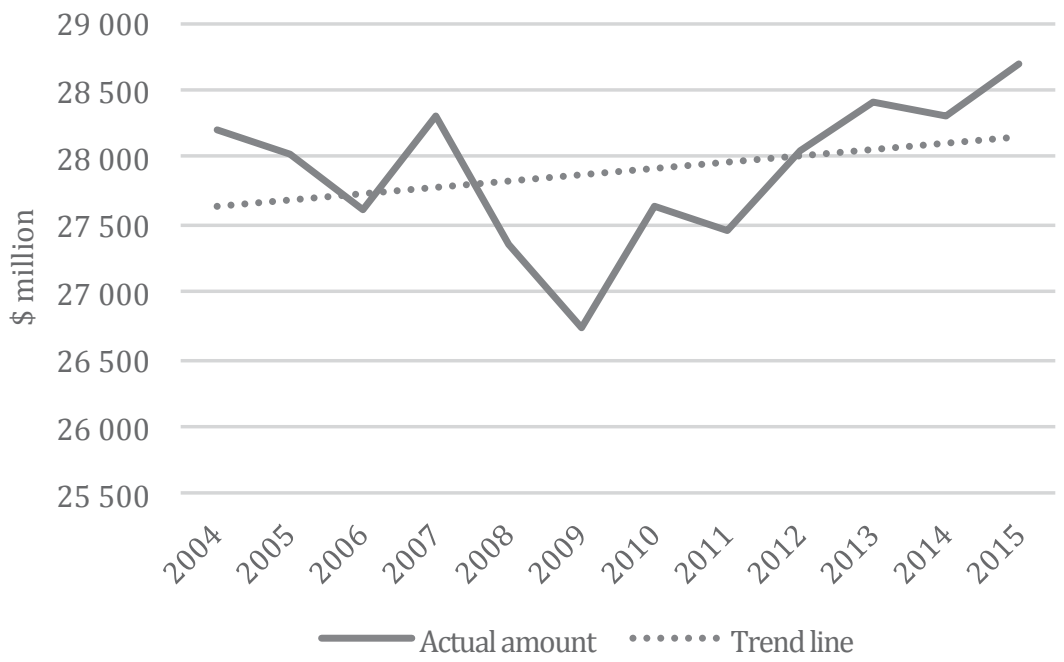

Figure 2.4 Total public sector road-related revenue in Australia (2015 prices)

Source: BITRE (2016).

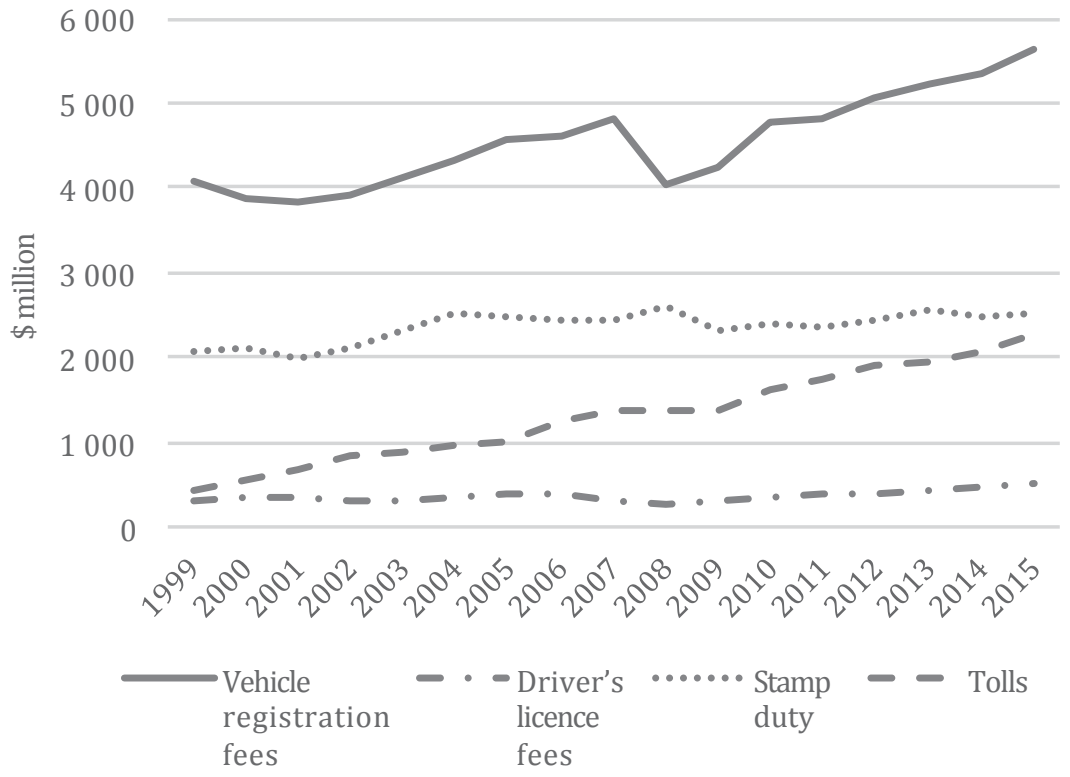

Figure 2.5 State and territory road-related revenue by type (2015 prices) Source: BITRE (2016). 
ROAD PRICING AND PROVISION

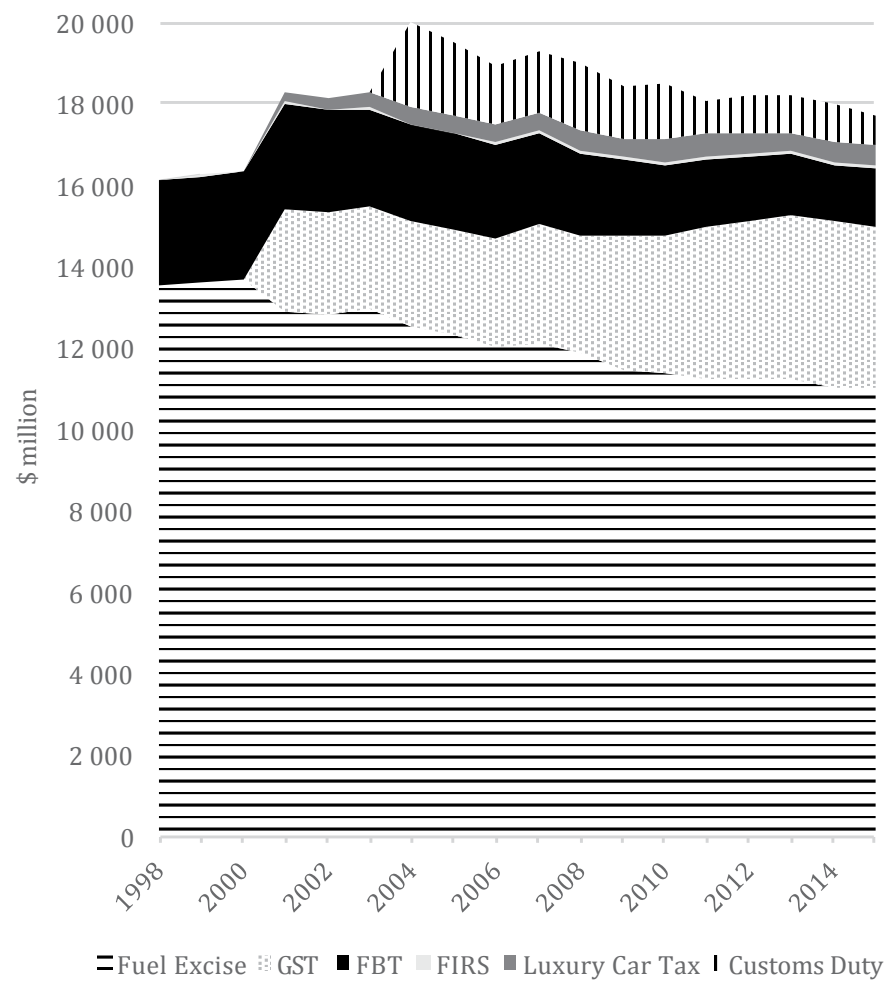

Figure 2.6 Commonwealth road-related revenue by type (2015 prices) Source: BITRE (2016).

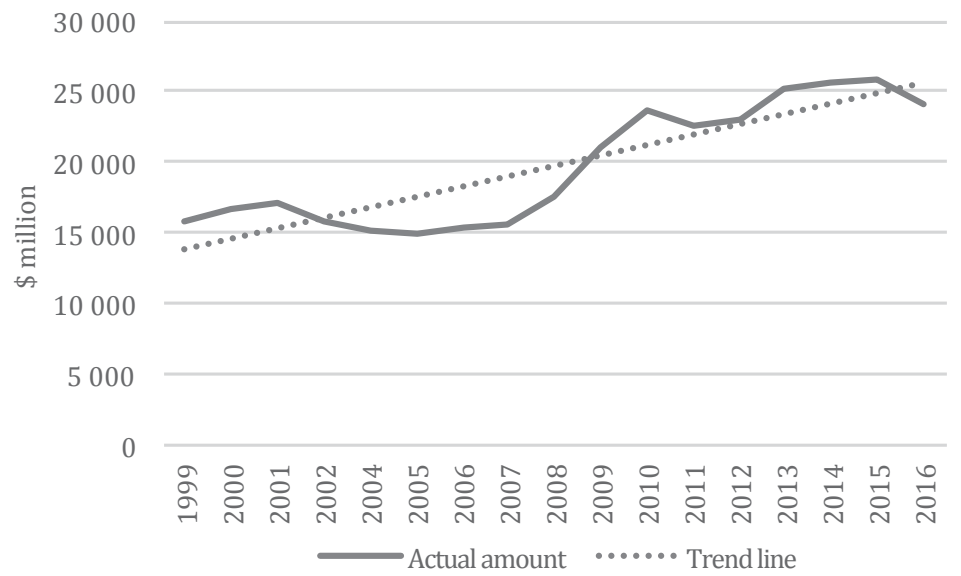

Figure 2.7 Total public sector road-related expenditure for Australia (2015 prices)

Source: BITRE (2016). 


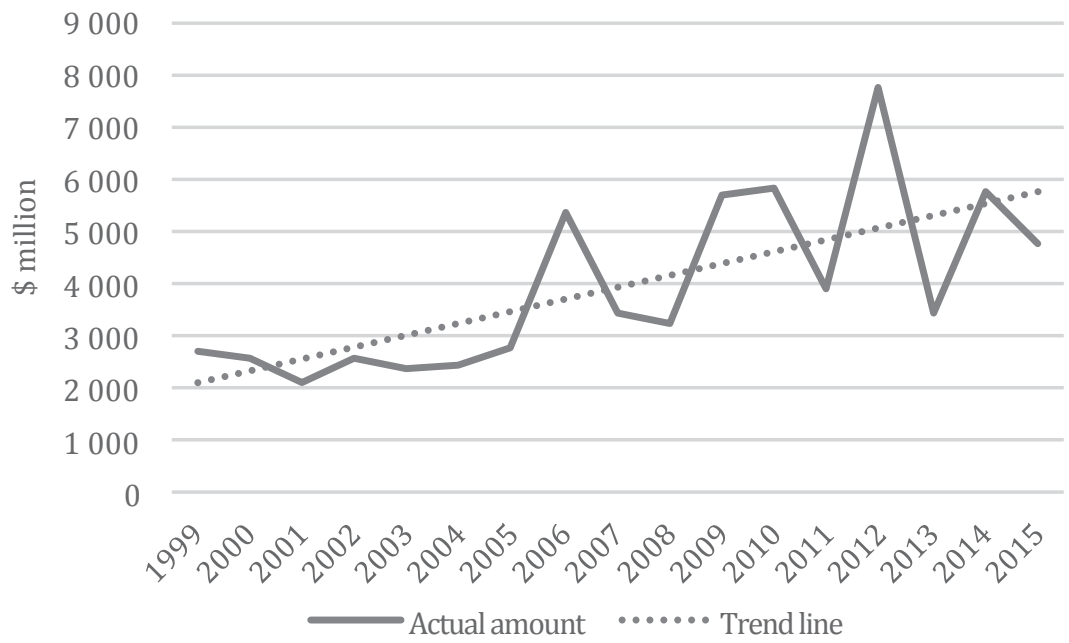

Figure 2.8 Total Commonwealth road-related expenditure (2015 prices) Source: BITRE (2016).

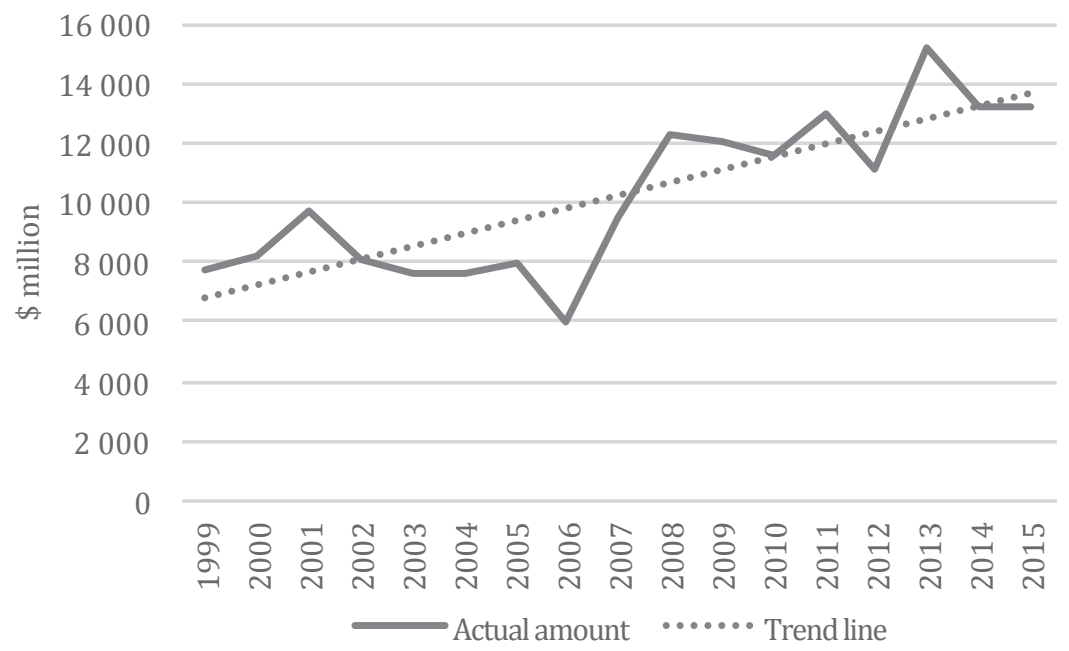

Figure 2.9 Total state and territory government road-related expenditure (2015 prices)

Source: BITRE (2016). 


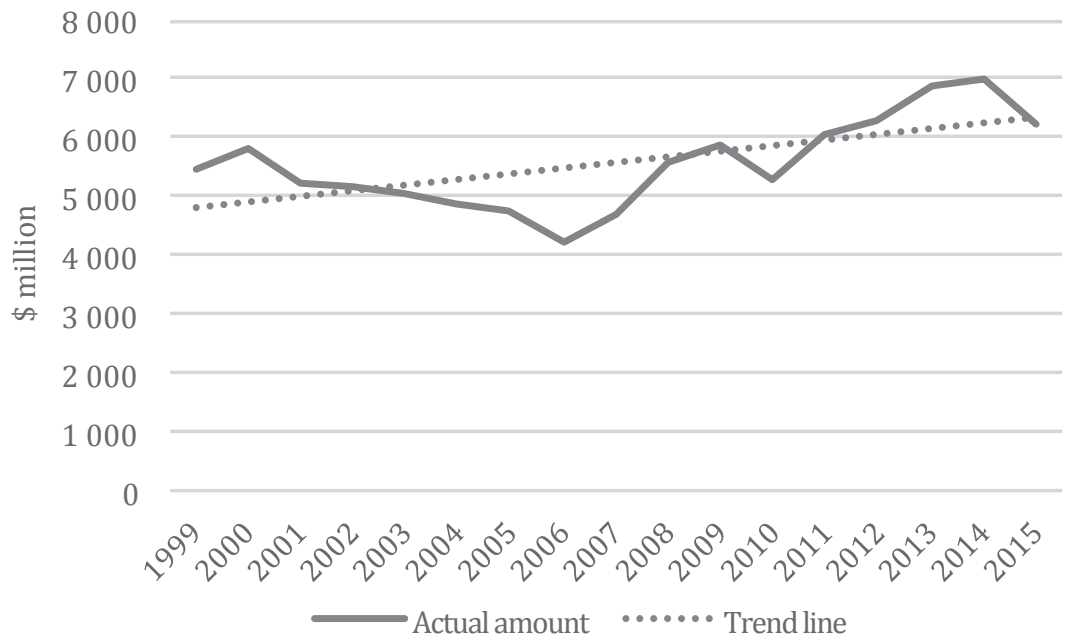

Figure 2.10 Total local government road-related expenditure (2015 prices)

Source: BITRE (2016).

In its examination of road-related revenue and expenditure trends, the Department of Infrastructure and Regional Development (DIRD 2016: 41) noted:

While there is only very limited hypothecation of road-related revenue to road expenditure, the cost of building and maintaining our roads is increasing at a rate faster than road-related revenue collected from motorists in taxes and charges.

Aspects of the current system of road-related fees and charges, such as fixed registration charges and stamp duty, do not provide a direct signal to road users about the cost of service provision and can encourage inefficient use of road services.

Population growth, urban development and changes in the broader economy will increase future demand on road infrastructure and, based on current trends, congestion is forecast to increase in major urban areas, which will constrain productivity. Without improved congestion management, the net social costs of congestion are expected to almost double over the next 15 years. The avoidable social cost of congestion in the eight Australian capitals was estimated to be approximately $\$ 16.5$ billion in the 2015 financial year [in 2010 dollars], rising from about $\$ 12.8$ billion in 2010 . These costs are projected to rise further to around $\$ 30$ billion by 2030 without measures to cut congestion. 
Clearly, the long-established mix of road-related revenue and expenditure is unsustainable into the future, and the idea of hypothecation is not new. Indeed, when it was introduced in 1929, the fuel excise was tied to road funding, and this was not changed to general revenue until 1959. Roadrelated revenue may not be tied to roads, but consumers expect it to be so. But consumers are not the only ones who are reluctant to see a change to how we pay for roads. Since 1959, successive federal governments have been reluctant to restrict their ability to raise general revenue and to tie policy expenditure to hypothecated revenue. There is some merit to this principle. In 1990, then minister for land transport in the Australian Labor Party Government, Bob Brown, explained:

[In] our seven years we have increased funding in a period of very tight fiscal restraint by 18 percent over and above the seven years of our predecessors. That represents, in terms of dollars, an additional $\$ 19.6$ billion in today's terms, in today's prices that we've put into the road system. We shouldn't, any more than we say we'll determine how much we'll put into education on the basis of how much income tax school teachers pay. That would be absurd. It's equally absurd for us to say that we will determine our level of road funding on the basis of how much tax motorists pay ... So we're not about y'know, that whole question of hypothecation, determining how much we'll put into roads on the basis of how much tax comes from any particular source. (Department of Prime Minister and Cabinet 1990)

An important change to note, however, is that, by 1990, the federal government had taken a lead role in funding roads, one that had been steadily increasing since the removal of protection from state rail services. The increasing demand for road freight transport led to the Commonwealth Aid Roads Act 1959, which ceased hypothecation of fuel excise and introduced a formula for allocating funds to states based on a combination of population, area and the number of registered vehicles with a quota of state funding to be provided to obtain the allocated federal funding (but out of consolidated revenue) (Clark 1988: 285). By 1969, the Commonwealth Bureau of Roads (CBR) had been established and increasingly sophisticated formulas were adopted to achieve efficiency measures in investment allocation in line with growing demand for roads. The CBR 'recommended the creation of a system of national highways' and, by 1974, 'program approval was required for state road expenditure to ensure that "national objectives [were] taken fully into account"' (Jones 1974: 382, cited in Clark 1988: 287). Constitutionally, the Commonwealth could not direct or enforce specific levels of state 
expenditure on roads. However, its various leveraging formulas enabled it to withhold funding from the states if national objectives were not being achieved through state expenditure. Hence, the Commonwealth was gradually able to 'impose its will' on the states (Clark 1988: 287).

While some state discretion was preserved during the Fraser Government's 'New Federalism' period, the Australian Bicentennial Road Development (ABRD) program adopted a hypothecated fuel tax (in addition to the fuel excise) from 1982 to 1988 to fund Commonwealth road projects through a form of specific-purpose grants. This enabled the Commonwealth to leverage control over policy areas of state responsibility, and was showcased by road signs advertising the Commonwealth's role in funding roads for the community. Since this period in particular, the constitutional powers over roads generally ascribed to the states have been in conflict with the Commonwealth's financial powers, and an accepted formula for funding roads remains a sore point with the states (Clark 1988: 287; Head et al. 1990; Holderhead 2017). Despite improved government marketing of road funding initiatives, and increased road funding being used for election purposes, the period from the late 1980s until the early 2000 s witnessed generally flat growth in funding, with the Commonwealth providing the smallest share of the three tiers of government (Webb 2004: 16). Nevertheless, Commonwealth funding of roads has trended upward and road funding continues to play a politically important role, such as the Roads to Recovery program, which will provide some $\$ 4.4$ billion from 2013-14 to 2020-21 'to Australia's local councils, state and territory Governments responsible for local roads' (DIRD 2017b). So, finding the right formula for reform will require a significant shift of the debate on road pricing and provision if the emerging institutional framework is to be sustainable.

\section{Where we live, how we commute and ideas about equity}

Urban sprawl has been a perennial feature of Australian cities, predicated on the widespread take-up of the motor car. The use of cars as a major mode of travel continued to grow from the 1920s until the mid-2000s, after which car use has generally levelled out or appeared to decline on a per capita basis. There has been much research into this observed phenomenon seeking to explain the reasons behind this historical 'peak' and then slightly declining trend. Three alternative hypotheses have been 
proposed-namely, 'peak car usage', 'saturation of use' and 'interrupted growth' (OECD and ITF 2013). Peak car usage is based on the idea that the number of kilometres travelled by privately owned cars has reached its finite peak, and the car as an essential means of individual transport is therefore on the decline. Reasons for the decline in motor vehicle usage include changes in attitudes towards living conditions and the preference of professionals, particularly the younger generation, to live in inner cities and commute via public transport, cycling and walking. Living in the inner city, the need for a car is decreased. Newman (2015) suggested that, by 2004, the peak in car usage had occurred in all major Australian cities, and therefore fears about increasing urban traffic congestion were unfounded (see Newman and Kenworthy 2011). Increased congestion was generally portrayed as a major policy challenge by authorities such as Infrastructure Australia (2015), in the Australian Infrastructure Audit, and BITRE (2015a), in the State of Australian Cities 2014-2015 report. Newman suggested the observable travel behaviours of younger generations were changing and, accordingly, he proposed better planning for travel by modes such as cycling, walking and light rail. He argued that, as car travel on a per capita basis continued to decline, these alternative modes of transport would further decrease demand for urban car usage and thus alleviate congestion problems.

While it may be plausible that car usage has peaked on the basis of per capita kilometres travelled by car, this does not necessarily mean a reduction in traffic congestion on highly congested road systems. Indeed, the modelling by Infrastructure Australia (2015) and BITRE (2015b) has predicted the major driver of urban traffic congestion will be population growth rather than the number of kilometres travelled by individual drivers. Although car use has historically increased as incomes have risen, BITRE's (2015b: 5) projections adopt the 'saturation' hypothesis, in which car use as a proportion of population is expected to peak by 2020 because 'people are spending as much time on daily travel as they are willing to commit; and are loath to spend any more of their limited time budgets on yet more travel, even if incomes do happen to rise'.

Interrupted growth is a worst-case scenario. According to this hypothesis, car usage has slowed due to a combination of 'national incomes measured as GDP per head, population, and fuel cost of motoring' (Goodwin 2013: 78). However, based on what is assumed about future combinations of these factors, 'car traffic will continue to grow, albeit at a slowing rate, for several decades into the future' (OECD and ITF 2013: 78). The above 
three approaches to understanding car use are merely plausible hypotheses, and therefore inconclusive in determining future trends in individual car use. BITRE's approach is to adopt 'saturation' as the middle position, where road use will remain at present rates for the medium term, but congestion will remain an issue due to population growth (BITRE 2015b: 7). Such a conservative approach is warranted, given the emergence of self-driving or driverless cars.

Driverless cars present a major opportunity to reduce traffic congestion by automating driving actions and organising (or 'platooning') vehicles to allow for more efficient traffic flow (Mikulski 2010: 45). But driverless cars are no instant panacea for sound infrastructure design; existing road bottlenecks can create traffic congestion, even for driverless cars (American Highway Users Alliance 2015). Further, Fulton (from the University of California, Davis, Institute of Transportation Studies, cited in Muoio 2017) has drawn attention to the need for a system of road pricing even with driverless vehicles. He stated:

[A] utonomous vehicles won't fix congestion woes unless a pricing system is put in place that discourages zero-occupancy vehicles ... We are especially concerned about zero-occupant vehicles that can happen with automated vehicles ... That scenario is especially plausible with private ownership of those vehicles and no limits to what we can do with them ... For example, many companies are interested in programming autonomous cars to run errands or pick up packages, but these efforts could increase traffic by multiplying the number of zero-occupant cars, or 'zombie cars' ... I think it's going to take some kind of pricing system that discourages zerooccupant vehicles and also makes penalties for single-occupancy vehicles.

Without a system of road pricing, it will also be difficult to incentivise a reduction of single-occupant vehicles on our roads. But this is predicated on people's willingness to share vehicles with others. Otherwise, the trend of single-occupant vehicles during peak traffic periods will not end with driverless vehicles. For example, Amman, the capital of Jordan (in the Middle East), has a two-tier taxi service. The more expensive service is a traditional book, hail and ride service, whereas the less expensive 'service' ${ }^{2}$ taxis run on set routes with set stops, accepting passengers until the car is full. The resulting behaviours mean that rich people take traditional taxis and poor people take service taxis. Rather than efficiency, complex (or even superficial) ideas about class, taste, dignity and economic capacity can determine users' transport behaviours (see Veblen 1994). Studies of

2 In the French pronunciation of the word. 
public transport have made similar conclusions: people are happy for governments to fund or subsidise public transport for others, but will continue to drive private vehicles for their own transport requirements (ARRB 2016; Carey 2016; Carrel et al. 2013). ${ }^{3}$ And these trends are not necessarily consistent over time: a person living in high-density housing in Surry Hills in Sydney in the 1920s and catching the tram to work is a far cry, for example, from a person living in high-density housing in Surry Hills today and commuting on light rail. Where we live and how we travel have as much to do with trends, tastes and societal preferences as they do with efficiency and economy.

Increasing medium- to high-density inner-city housing means transport infrastructure such as bus and light rail services becomes less expensive for individuals as demand increases, and the shorter distances mean that transport infrastructure investment is more efficient, in that its supply, in a smaller geographical area, meets a concentrated demand. The preference for investment in light rail in Canberra, the Gold Cost, Sydney and Adelaide, for example, is based on the premise of higher-density housing located closer to where people work. While not necessarily requiring less investment in terms of infrastructure spending, transport infrastructure that serves a densely populated, discrete area enables greater potential return on investment due to high demand. For example, while a highspeed rail system between Melbourne and Sydney might enable people to live further from the central business districts, and the speed of the service ensures a shorter time for commuting, the return on investment depends on the number of people accessing the service from more distant places. Compare this with a light rail service in an area of high-density housing: the investment in light rail is less, but the demand for the service is considerably higher given the number of potential users of the service. For a high-speed rail service, which necessarily requires greater investment outlay, the consumer price for the service is considerably higher to achieve a commensurate rate of return on that investment. Given the potentially lower demand from a lower number of users in lower-density areas, there is a trade-off for the commuter in terms of the cost of using a high-speed rail service versus the cost of using a private car, but this may be offset by lower property prices. In terms of systemic efficiency, if light rail were to reduce the number of cars on inner-city roads then, paradoxically, there is an incentive for the use of private cars by those living outside the area serviced by light rail. So the modal mix becomes important in transport

3 For attitudes towards public transport in popular culture, see Jaffe (2015); The Onion (2000). 
management, along with pricing and value capture or, alternatively, instances of policy tinkering in one area may create unforeseen behavioural problems in another.

The obvious trade-off with inner-city transport infrastructure is that property prices will increase in areas serviced by light rail, while properties further away from the CBD will remain less expensive. This means that, in the absence of alternative modes, less-wealthy people will continue to live further out and continue to rely on private vehicles, while wealthier people will enjoy the benefits of concentrated transport infrastructure, typically provided through public funding. This raises an issue of social equity, in that governments cross-subsidise the wealthy by providing transport infrastructure that does not service those who cannot afford to live in high-density, inner-city areas. Further, the road network that sustains those living in lower-density, outer-city areas is less efficient if it continues to be provided as a public good and will have little impact on transport behaviours unless alternative modes of transport are made available.

The hypothetical scenarios outlined above lead policymakers to consider two necessary interventions to capture these relevant externalities. First, some form of 'value capture' from improved land values is necessary to ensure that wealthier, inner-city property owners do not receive a freerider benefit from increased property values brought about by public investment in transport infrastructure. Second, a form of discretionary road pricing is necessary to ensure that those who use the roads pay for that use. In the present system, behaviours become established in the absence of the true cost of externalities. A wealthy person can live in the inner city and take advantage of public transport, thereby reducing the individual's transport costs, whereas a less wealthy person would be better off living further from their place of employment and using their private car to commute. Such problems of equity make it difficult to balance social policy with economic policy outcomes. For Infrastructure Australia (2013: 17):

The best approach to urban transport funding may be to source all funds directly from users or beneficiaries. The aim would be to encourage optimal travel behaviour and moderate demand, as well as provide finance for services and infrastructure. In an ideal world revenues would be higher than financial costs in order to account for externalities ... However, such an approach has not been adopted. Also, it may prove infeasible; for example in some circumstances it may be more efficient to collect taxes than user charges. 
In the absence of appropriate pricing systems to 1) capture increased property values and 2) provide price signals for demand for transport infrastructure, there is little rational basis for investing in transport infrastructure other than for election purposes.

\section{The path to road reform: A predilection for reporting, not acting}

Three major inquiries relating to market reform, revenue reform and productivity have reported to the federal government: the Hilmer competition law review in 1993, the Henry review of tax in 2010 and the Harper review of productivity in 2014. In each case, the slow pace of reform, the lack of sustainability of the present funding arrangements and the inefficiency of the road transport sector (respectively) were noted. Further, many public submissions to the inquiries pointed to the road transport sector as an area of concern. The Hilmer review on competition law (Hilmer et al. 1993: 14) noted the progress on reforms such as those for rail and heavy vehicles while acknowledging that 'the community generally [was] impatient for much more rapid progress by governments in reforming our infrastructure and regulatory systems'. Road construction was not yet subject to consistent competitive tendering and Commonwealth-state cooperation on road transport was 'likely to be successful, though the pace of such cooperative effort [was] at times of concern' (Hilmer 1993: 209-10, 298). Further, Hilmer et al. (1993: 201) found 'a vast amount of regulation ... [was] perceived to be restricting competition without adequate justification'. By the time of the Hilmer review, major market reforms were well under way in telecommunications (Dobes 1991), water (Tisdell et al. 2002: iii) and energy (AEMC 2017), ${ }^{4}$ but, by comparison, the rate of reform of the road transport sector has been glacial. ${ }^{5}$

4 Energy sector reform began in 1991 and, in 1995, the Council of Australian Governments (COAG) endorsed the recommendations of the Hilmer review.

5 The Federal Interstate Registration Scheme (FIRS) for heavy vehicles (weighing more than 4.5 tonnes) began with the Interstate Road Transport Act 1985, and came into effect in 1987 as an alternative to state-based registration (DIRD 2017a). The purpose of the Productivity Commission's (2016) report was 'to assist COAG to implement efficient pricing of road and rail freight infrastructure' (see Chapter 9, this volume). But the harmonisation of national heavy vehicle laws was not consolidated until 2013, when the Heavy Vehicle National Law (HVNL) came into effect. Further, user charges for heavy vehicles based on actual use are still a few years away, with light vehicle user charges expected to take some 15 years (Fletcher, cited in Chang 2016). 
The Henry review (Henry et al. 2010) found:

Current road tax arrangements will not meet Australia's future transport challenges. (p. 53)

... Transport-specific taxes should only be imposed where they improve the way that people, businesses and governments make decisions. In general, this means that transport taxes should be designed to correct market failures in the transport sector. (p. 375)

... The existing structure of fuel tax, annual registration and other roadrelated taxes is designed primarily to raise revenue. These taxes more than cover the direct costs of providing road infrastructure, but are not capable of providing specific prices that vary according to location or time of use. (p. 376)

... Governments should analyse the potential network-wide benefits and costs of introducing variable congestion pricing on existing tolled roads (or lanes), and consider extending existing technology across heavily congested parts of the road network. Beyond that, new technologies may further enable wider application of road pricing if proven cost-effective. In general, congestion charges should apply to all registered vehicles using congested roads. (p. 377)

In 2014, the Harper review (Harper et al. 2015: 1) found that road reform was 'one of the top five issues most often raised in submissions', and it: recommend[ed] reforming road transport by introducing cost-reflective road pricing in a revenue-neutral way and linked to road construction, maintenance and safety so that road investment decisions are more responsive to the needs and preferences of road users. (p. 8)

\section{Further:}

[I]n roads there has been little progress introducing pricing that reflects the actual cost of use on the network, such as time and location charging. Investment in those sectors is either funded directly from budgets or by users across the network rather than from users according to the costs they impose on the network. Roads in particular have also been subject to investment bottlenecks. (p. 194)

... [T] here has been little progress in attempting to introduce costreflective pricing in roads and linking revenue to road provision. As a consequence, there is criticism that new roads are being built in the wrong places for the wrong reasons, while too little attention is paid to getting more efficient use of existing road infrastructure. (p. 195) 
Clearly, road pricing and provision are complex, but the reform process has been inordinately slow.

An interesting feature of the road transport sector in Australia is the immensely detailed and documented research and reporting that have occurred over the decades. Yet the Harper review (Harper et al. 2015: 38) found that 'roads are the least reformed of all infrastructure sectors, with institutional arrangements around funding and provision remaining much the same as they were 20 years ago'.

Given the extent of reporting on road reform over the years, from a policy perspective, it is surprising that progress has been so slow. For commuters in the major metropolitan centres, the daily realities of Australia's road networks should be enough to persuade any rational voter to call for change. But generational habits have a peculiar way of being hard to give up, as the Bureau of Transport Economics (BTE 1977: 147-8) discovered when considering road user charging (then referred to as 'cost recovery') some 40 years ago:

The BTE's view is that private motor vehicle operation is essentially outside the framework of this study. This statement is not made merely to sidestep a difficult issue, but has sound philosophical grounds. In every other mode of transport, the major services are offered to the public through marketing agencies of various sorts (airlines, railways and so on). Whether such agencies operate at a profit or not is irrelevant in this sense. The fact is that such agencies form an identifiable interface between a complex background organisational structure and an individual user. The same applies for commercial road freight transport, where an end user of a transport service pays one fee to one organisation, and need not be aware of the complete organisational structure which leads to the setting of that fee. However, this system breaks down when private (i.e. not hire and reward) motor transport is considered. The private motor vehicle operator is, in many senses, on his own. In essence, he is a user of the road system, rather than a transport service.

The absence of point-of-sale pressure on road users' transport behaviours reinforces the status quo. This means reform is not a simple process, and yet another report will not make the transition any easier. But there has been some positive policy action that may see the long-overdue reforms placed firmly on the policy agenda. 


\section{Conclusion: A time for action}

On 24 November 2016, Paul Fletcher, the Minister for Urban Infrastructure and Cities (2016a, 2016c; see also Chang 2016), announced that the Turnbull Government had committed to implementing five key initiatives of Infrastructure Australia's (2016) 15-year infrastructure plan. Further reform of heavy vehicle charges will be the priority, while the costs and benefits of a road user charging system for light vehicles will be investigated. The media release gave an indicative timeline of 10 to 15 years. This follows the minister's earlier call for submissions to a discussion paper on the wider use of value capture to fund infrastructure (Fletcher 2016b). Further, the minister echoed Infrastructure Australia's (2016: 87) words and agreed that public knowledge of the existing road funding regime is limited, with most citizens adverse to any form of charges, regarding them as a 'new tax'. Road reform will no doubt 'require the removal of familiar taxes and charges such as excise on fuel and registration fees' (Infrastructure Australia 2016: 87). At least a lack of research reports should not prove a stumbling block.

Public perception is the key issue affecting the ability of governments to be decisive in reforming this important productivity and revenue issue for Australia. Road pricing offers a 'doable' policy response to a major source of frustration for millions of Australians who experience traffic congestion every working day. The research has been done, the reports have been written, we have the technology and a consensus has formed among the key industry players. This is important: already the Australian Automobile Association is calling for changes to fuel receipts to show consumers how much tax they are paying at the pump (Coorey 2016). Yet the biggest challenge will be getting the states and territories on board. The states may baulk at yet another Commonwealth revenue grab after the experience of John Howard's legacy GST arrangements, or a 'GST birthday cake' may stall the process, and a lot will be riding on Minister Fletcher's recently announced 'eminent person' to champion the reform transition. Either way, finally, it appears that road reform is firmly on the political agenda. 


\section{References}

American Highway Users Alliance. (2015). Unclogging America's Arteries 2015: Prescriptions for Healthier Highways. Washington, DC: American Highway Users Alliance. Available from: www.highways.org/wp-content/uploads/ 2015/11/unclogging-study2015-hi-res.pdf (accessed 2 August 2017).

Anthony, S. (2016). Super funds must boldly go where few investors will: 'greenfield' public infrastructure. The Canberra Times, 5 December. Available from: www.canberratimes.com.au/national/public-service/super-fundsmust-boldly-go-where-few-investors-will-greenfield-public-infrastructure20161129-gt01c7.html (accessed 1 August 2017).

Australian Bureau of Statistics (ABS). (2017a). Australian National Accounts: National Income, Expenditure and Product, March 2017. Cat. no. 5206.0. Canberra: ABS. Available from: www.abs.gov.au/ausstats/abs@.nsf/mf/ 5206.0 (accessed 1 August 2017).

Australian Bureau of Statistics (ABS). (2017b). Engineering Construction Activity, Australia, March 2017. Cat. no. 8762.0. Canberra: ABS. Available from: www.abs.gov.au/ausstats/abs@.nsf/mf/8762.0 (accessed 1 August 2017).

Australian Energy Market Commission (AEMC). (2017). History of Energy Market Reform. Sydney: AEMC. Available from: www.aemc.gov.au/about-us/ history (accessed 3 August 2017).

Australian Road Research Board (ARRB). (2016). Omnibus Survey Results: Congestion. Research Report, 14 April. Melbourne: ARRB. Available from: cdn2.hubspot.net/hubfs/3003125/Major_Functions/PDF/ARRB\%20 Research\%20report\%20on\%20congestion\%20-\%2014\%20April\%202016. pdf?t=1501211172699 (accessed 2 August 2017).

Bureau of Infrastructure, Transport and Regional Economics (BITRE). (2014). Infrastructure, Transport and Productivity. Information Sheet 55. Canberra: Commonwealth of Australia.

Bureau of Infrastructure, Transport and Regional Economics (BITRE). (2015a). State of Australian Cities 2014-2015. Canberra: Commonwealth of Australia. Available from: infrastructure.gov.au/infrastructure/pab/soac/files/2015_ SoAC_full_report.pdf

Bureau of Infrastructure, Transport and Regional Economics (BITRE). (2015b). Traffic and Congestion Cost Trends for Australian Capital Cities. Information Sheet 74. Canberra: Commonwealth of Australia. 
Bureau of Infrastructure, Transport and Regional Economics (BITRE). (2016). Yearbook 2016: Australian Infrastructure Statistics. Statistical Report. Canberra: Commonwealth of Australia.

Bureau of Transport Economics (BTE). (1977). Cost Recovery in Australian Transport 1974-75. Canberra: Australian Government Publishing Service. Available from: bitre.gov.au/publications/1977/files/report_033.pdf (accessed 15 January 2017).

Carey, A. (2016). Australian commuters would rather sit in traffic than on a train, survey finds. The Age [Melbourne], 13 April. Available from: www.theage. com.au/victoria/australian-commuters-would-rather-sit-in-traffic-than-on-atrain-survey-finds-20160413-go5lqw (accessed 2 August 2017).

Carrel, A., Halvorsen, A. and Walker, J. (2013). Passengers' perception of and behavioral adaptation to unreliability in public transportation. Transportation Research Record: Journal of the Transportation Research Board 2351: 153-62. doi.org/10.3141/2351-17

Chang, C. (2016). Turnbull Government considers new user pays system for cars. News.com.au, 23 November. Available from: www.news.com.au/ finance/economy/australian-economy/turnbull-government-considers-newuser-pays-system-for-cars/news-story/0bab973c586f9a730e869549113840 $8 f$ (accessed 3 August 2017).

Clark, R. G. (1988). Australian federal government road funding 1972-1986. Australian Geographical Studies 26(2): 279-94. doi.org/10.1111/j.14678470.1988.tb00579.x

Coorey, P. (2016). Transition to road user charge inevitable. Australian Financial Review, 24 November. Available from: www.afr.com/news/transition-toroad-user-charge-inevitable-20161123-gsw8i0 (accessed 4 August 2017).

Department of Infrastructure and Regional Development (DIRD). (2014). Trends: Infrastructure and Transport to 2030. Canberra: Commonwealth of Australia.

Department of Infrastructure and Regional Development (DIRD). (2016). Trends: Infrastructure and Transport to 2040. Canberra: Commonwealth of Australia.

Department of Infrastructure and Regional Development (DIRD). (2017a). Federal Interstate Registration Scheme. Canberra: Commonwealth of Australia. Available from: infrastructure.gov.au/roads/firs/index.aspx (accessed 20 July 2018). 
Department of Infrastructure and Regional Development (DIRD). (2017b). Roads to Recovery Program. Canberra: Commonwealth of Australia. Available from: investment.infrastructure.gov.au/funding/r2r/ (accessed 3 August 2017).

Department of the Prime Minister and Cabinet. (1990). Transcript of joint news conference with the Hon. Bob Brown, Minister for Land Transport, Sheraton Hotel, Brisbane, 27 February 1990. Transcript ID 7931. Available from: pmtranscripts.pmc.gov.au/release/transcript-7931 (accessed 3 August 2017).

Desloires, V. (2016). Global infrastructure set for rerating as private equity dives in. Sydney Morning Herald, 26 October. Available from: www.smh.com.au/ business/markets/global-infrastructure-set-for-rerating-as-private-equitydives-in-20161025-gs9w7v.html (accessed 1 August 2017).

Dobes, L. (1991). The telecommunications reform process in Australia. Telecommunications Journal of Australia 41(1): 3-7.

Fitchett, T. K. (1976). The Vanished Fleet: Australian Coastal Passenger Ships 1910-1960. Adelaide: Rigby.

Fletcher, P. (2016a). Speech to the Sydney Institute, 16 August. Available from: minister.infrastructure.gov.au/pf/speeches/2016/pfs007_2016.aspx (accessed 15 January 2017).

Fletcher, P. (2016b). Government seeks public and industry input on value capture. Media release, 16 November. Available from: minister.infrastructure.gov.au/ pf/releases/2016/November/pf078_2016.aspx (accessed 4 August 2017).

Fletcher, P. (2016c). Infrastructure Australia 15 year plan to guide key infrastructure policy directions for Turnbull Government. Media release, 24 November. Accessed 4 August 2017: paulfletcher.com.au/media-centre/media-releases/ item/1842-infrastructure-australia-15-year-plan-to-guide-key-infrastructurepolicy-directions-for-turnbull-government.html (site discontinued).

Goodwin, P. (2013). Peak travel, peak car and the future of mobility: Evidence, unresolved issues, policy implications and a research agenda, in Long-Run Trends in Car Use. Paris: OECD Publishing. doi.org/10.1787/9789282105931-en

Hancock, W. K. (1930). Australia. London: E. Benn.

Harper, I., Anderson, P., McCluskey, S. and O’Bryan, M. (2015). Competition Policy Review: Final Report March 2015. Canberra: Commonwealth of Australia. Available from: competitionpolicyreview.gov.au/files/2015/03/ Competition-policy-review-report_online.pdf (accessed 12 August 2017). 
Head, B., Wanna, J. and Warburton, J. (1990). Implications of 'Fiscal Centralisation' for Public Sector Management in Australia. Research Paper No. 11, February. Centre for Australian Public Sector Management. Brisbane: Griffith University.

Henry, K., Harmer, J., Piggott, J., Ridout, H. and Smith, G. (2010). Australia's Future Tax System: Report to the Treasurer, Detailed Analysis Volume 2. Canberra: Commonwealth of Australia.

Hilmer, F. G., Rayner, M. R. and Taperell, G. Q. (1993). National Competition Policy: Report by the Independent Committee of Inquiry. Canberra: Commonwealth of Australia. Available from: ncp.ncc.gov.au/docs/ National\%20Competition\%20Policy\%20Review\%20report,\%20The\%20 Hilmer\%20Report,\%20August\%201993.pdf

Holderhead, S. (2017). Anger as SA 'dudded' in budget. The Advertiser [Adelaide], 10 May. Available from: www.adelaidenow.com.au/news/south-australia/ federal-government-shortchanged-sa-300-million-in-infrastructure-spending/ news-story/5119968fd765c773af3d38469184108d (accessed 3 August 2017).

Infrastructure Australia. (2013). Urban Transport Strategy, December 2013. Sydney: Infrastructure Australia.

Infrastructure Australia. (2015). Australian Infrastructure Audit. Sydney: Infrastructure Australia. Available from: infrastructureaustralia.gov.au/policypublications/publications/Australian-Infrastructure-Audit.aspx

Infrastructure Australia. (2016). Australian Infrastructure Plan: Priorities and Reforms for Our Nation's Future. Sydney: Infrastructure Australia. Available from: infrastructureaustralia.gov.au/policy-publications/publications/Australian -Infrastructure-Plan.aspx

Infrastructure Finance Working Group (IFWG). (2012). Infrastructure Financing and Funding Reform: Report Prepared by the Infrastructure Finance Working Group, April 2012. Sydney: Infrastructure Australia. Available from: infrastructureaustralia.gov.au/policy-publications/publications/InfrastructureFinance-Reform-Issues-Paper-Report-prepared-by-the-Infrastructure-FWG2012.aspx (accessed 2 August 2017).

Jaffe, E. (2015). Buses are for other people. The Atlantic, January-February. Available from: www.theatlantic.com/magazine/archive/2015/01/buses-arefor-other-people/383513/ (accessed 2 August 2017). 
Juturna Consulting. (2012). Economic Reform of Australia's Road Sector: Precedents, Principles, Case Studies and Structures. Juturna Consulting for Infrastructure Australia, February. Available from: infrastructureaustralia.gov.au/policypublications/publications/files/Competition_Reform_of_the_Road_Sector. pdf (accessed 1 August 2017).

Laird, P. (2014). Australia's transport is falling behind on energy efficiency. The Conversation, 27 August. Available from: theconversation.com/ australias-transport-is-falling-behind-on-energy-efficiency-29881 (accessed 1 August 2017).

Le Corbusier, C.-E. (1987 [1929]). The City of Tomorrow and its Planning. New York: Dover.

Mikulski, J. (ed.). (2010). Transport Systems Telematics: 10th Conference, TST 2010, Katowice-Ustron, Poland, October 20-23, 2010. Selected papers. Berlin: Springer. doi.org/10.1007/978-3-642-16472-9

Muoio, D. (2017). Why self-driving cars could be terrible for traffic. Business Insider, 5 June. Available from: www.businessinsider.com.au/self-drivingcars-traffic-congestion-2017-6 (accessed 2 August 2017).

Newman, P. (2015). Don't panic! Traffic congestion is not coming for our cities. The Conversation, 27 July. Available from: theconversation.com/dont-panictraffic-congestion-is-not-coming-for-our-cities-45154 (accessed 3 January 2017).

Newman, P. and Kenworthy, J. (2011). 'Peak car use': Understanding the demise of automobile dependence. World Transport Policy \& Practice 17(2): 31-42.

Organisation for Economic Co-operation and Development (OECD). (2010). Economic Survey of Australia 2010. Paris: OECD.

Organisation for Economic Co-operation and Development (OECD). (2012). Economic Survey of Australia 2012. Paris: OECD.

Organisation for Economic Co-operation and Development (OECD). (2014). Economic Survey of Australia 2014. Paris: OECD.

Organisation for Economic Co-operation and Development (OECD). (2017). Economic Survey of Australia 2017. Paris: OECD.

Organisation for Economic Co-operation and Development (OECD) and International Transport Forum (ITF). (2013). Long-run trends in car use. Round Tables, No. 152. Paris: OECD Publishing/ITF. 
O'Rourke, J. (2015). Toll war revs up: Sydney drivers face congestion tax or road user-pay system. Sunday Telegraph, 12 July. Available from: www. dailytelegraph.com.au/news/nsw/toll-war-revs-up-sydney-drivers-facecongestion-tax-or-road-user-pay-system/story-fni0cx12-1227438090226 (accessed 12 July 2015).

Pigou, A.C. (1920). The Economics of Welfare. London: Macmillan.

Productivity Commission. (2016). Road and Rail Freight Infrastructure Pricing. Report No. 41. Canberra: Productivity Commission.

Saleh, L. (2015). Editorial: Nothing tolls for me. Sunday Telegraph, 12 July.

Standing Committee on Infrastructure, Transport, Regional Development and Local Government and King, C. (2008). Rebuilding Australia's Coastal Shipping Industry: Inquiry into Coastal Shipping Policy and Regulation. Canberra: Parliament of Australia. Accessed 28 April 2017: www.aph.gov. $\mathrm{au} /$ House/committee/itrdlg/coastalshipping/report.htm (site discontinued).

Sturgess, G. (1996). Virtual government: What will remain inside the public sector? Australian Journal of Public Administration 55(3): 59-73. doi.org/ 10.1111/j.1467-8500.1996.tb01223.x

The Age. (1954). States' answer to Privy Council ruling: Rail commissioners to hold conference. The Age [Melbourne], 29 November, p. 3.

The Onion. (2000). Report: 98 percent of US commuters favor public transportation for others. The Onion, 29 November. Available from: www. theonion.com/article/report-98-percent-of-us-commuters-favor-publictra-1434 (accessed 2 August 2017).

Tisdell, J. G., Ward, J., Grudzinski, T. and Cooperative Research Centre for Catchment Hydrology. (2002). The Development of Water Reform in Australia. Melbourne: CRC for Catchment Hydrology.

Veblen, T. (1994 [1899]). Theory of the Leisure Class. Mineola, NY: Dover.

Vickrey, W. (1948). Some objections to marginal-cost pricing. Journal of Political Economy 56(3): 218-38.

Vickrey, W. (1963). Pricing in Urban and Suburban Transport. American Economic Review 53(2): 452-65.

Webb. R. (2004). Commonwealth Road Funding since 1990. Research Paper No. 7 2003-04. Canberra: Parliamentary Library. Available from: www. aph.gov.au/About_Parliament/Parliamentary_Departments/Parliamentary_ Library/pubs/rp/rp0304/04rp07 
This text is taken from Road Pricing and Provision: Changed Traffic Conditions Ahead, edited by Michael de Percy and John Wanna, published 2018 by ANU Press, The Australian National University, Canberra, Australia.

doi.org/10.22459/RPP.07.2018.02 